\title{
Potential chemoprotective effects of green propolis, L-lysine and celecoxib on bone marrow cells and peripheral blood lymphocytes of Wistar rats subjected to bladder chemical carcinogenesis ${ }^{1}$
}

\author{
Conceição Aparecida Dornelas ${ }^{\mathrm{I}}$, Bruno Coelho Cavalcanti' ${ }^{\mathrm{II}}$, Hemerson Iury Ferreira Magalhães ${ }^{\mathrm{III}}$, Francisco Vagnaldo Fechine \\ Jamacaru $^{\text {IV }}$, Francisco Nelson Nóbrega Furtadov, Camila de Carvalho Juanes ${ }^{\mathrm{VI}}$, Nayanna de Oliveira Ramos Melo ${ }^{\mathrm{VI}}$, Manoel \\ Odorico de Moraes ${ }^{\mathrm{VII}}$
}

DOI: http://dx.doi.org/10.1590/S0102-86502014000700003

IPhD, Associate Professor, Department of Pathology, Federal University of Ceara (UFC), Brazil. Conception, design and scientific content of the study, technical procedures, manuscript writing.

IIPDD, Department of Physiology and Pharmacology, National Laboratory of Experimental Oncology, UFC. Perform and interpret the data of micronucleus and comet assays.

IIIPhD, Assistant Professor of Toxicology, Federal University of Paraiba (UFPB), Brazil. Perform of micronucleus and comet assays.

${ }^{\mathrm{IV}} \mathrm{PhD}$, Department of Physiology and Pharmacology, UFC, Fortaleza-CE, Brazil. Statistical analysis.

${ }^{v}$ Fellow Master degree, Postgraduate Program in Pathology, Medical School, UFC, Fortaleza-CE, Brazil. Acquisition of data.

${ }^{\mathrm{VI}}$ Graduate student, Scientific Iniciation Program, UFC, Fortaleza-CE, Brazil. Manuscript preparation.

${ }^{\mathrm{VII}}$ Chairman, Department of Physiology and Pharmacology, UFC, Fortaleza-CE, Brazil. Supervision all phases of the study.

\section{ABSTRACT}

PURPOSE: To evaluate the genotoxicity of propolis and $L$-lysine, as well as their effects on the possible cellular damage in erythroblasts (bone marrow) and leukocytes (peripheral blood) caused by the carcinogen BBN ( - butyl $-\mathrm{n}\{4-$ hydroxybutyl $\}$ nitrosamine) in rats subjected to bladder carcinogenesis and treated with green propolis and L-lysine.

METHODS: One hundred and twenty five rats were distributed into the following groups: I, IIA, IIB, III, K, L M N, X, XI, XII and XIII. Groups I to X received BBN in drinking water for 14 weeks (wks). Group I was treated with intragastric (ig) propolis at $150 \mathrm{mg} /$ $\mathrm{kg}$ body weight, for $44 \mathrm{wks}$, beginning 30 days before start of BBN. Groups IIA and III were treated with propolis (150 mg/kg), for 40 wks, subcutaneous (sc) and ig, respectively, beginning simultaneously with BBN. On the 32nd wk, the animals of groups L, M and N were treated ig with $L$-lysine $(300 \mathrm{mg} / \mathrm{kg})$, celecoxib $(30 \mathrm{mg} / \mathrm{kg})$ and propolis $(300 \mathrm{mg} / \mathrm{kg})$, respectively, up to the 40 th wk. The groups that received only BBN (IIB and K) were treated with water, sc and orally, respectively, for 40 wks. Groups XI, XII and XIII received respectively propolis $(150 \mathrm{mg} / \mathrm{kg})$, L-lysine $(150 \mathrm{mg} / \mathrm{kg})$ and water ig for $40 \mathrm{wks}$. After $40 \mathrm{wks}$, the surviving animals were anesthetized and subjected to femoral bone marrow aspiration and blood collection from the aorta, for CA and MNT, respectively, for investigation of genotoxicity.

RESULTS: Groups IIB and K, which received only BBN and water, showed the greatest DNA damage in peripheral leukocytes (CA) and largest number of micronuclei in bone marrow erythrocytes (MNT) in relation to all other groups that received BBN and lysine and/ or propolis $(\mathrm{p}<0.001)$.

CONCLUSIONS: Both propolis and L-lysine are effective in protecting against genotoxicity, as well not being genotoxic themselves toward the cells evaluated, at the doses and times administered and according to the two tests utilized.

Key words: Propolis. Lysine. Genotoxicity. Urinary Bladder Neoplasms. Rats. 


\section{Introduction}

We live in era of environmental genotoxicity. This is because of the direct action of the ingestion of contaminated food and water (preservatives, dyes, hormones, agrotoxins, industrial and radioactive residues) or by the inhalation of gases and heavy metals (burning fuels in large urban centers). Genotoxicity could occur indirectly by hepatic metabolism of everything that is ingested or inhaled daily. In the last five years, there have been 15.000 published studies investigating antimutagenic and anticarcinogenic substances, with the majority coming from plants. The comet assay (CA) and micronucleus test (MNT) are genotoxity tests that are utilized to determine DNA damage in individual cells and to detect chromosomal damage at the mitotic spindle, respectively.

Genotoxity tests are routinely utilized for the evaluation of the toxicological spectrum of chemical compounds and medications. Genetic toxicity is not a measure of carcinogenicity but is often used as an indicator for cancer since genotoxicity tests determine the initial and intermediate events of tumorigenesis ${ }^{1}$. The comet assay (CA) and micronucleus test (MNT) evaluate toxicity. $\mathrm{CA}$ is used to detect genomic alterations. The principle of CA is based on the migration of DNA in agarose during electrophoresis, as largely intact or fragmented molecules. MNT is utilized to detect chromosomal damage of the mitotic spindle, in which during the maturation of erythroblasts, the nucleus is expelled from the cell and in the absence of damage through breaks or damage in the mitotic spindle, where no residual chromatid (micronucleus) remains inside the cell. Propolis is a resin produced by bees that has various antineoplasic ${ }^{2}$, antiinflammatory ${ }^{3}$, immunomodulatory ${ }^{4}$ , antibacterial ${ }^{5}$ and antiangiogenesis properties ${ }^{6,7}$. L-lysine is an essential amino acid and has been utilized in the extraction of propolis since the patented proposal of Nicolov et al. ${ }^{8}$ up to recent publications ${ }^{2,3,7,9}$. The objective of this work was to study the genotoxicity of green propolis and $L$-lysine on the bone marrow of rats subjected to chemical carcinogenesis of the bladder.

\section{Methods}

One hundred and twenty five rats were distributed into following groups: I, IIA, IIB, III, K, L M N, X, XI, XII and XIII. Groups I to X received BBN for 14 weeks in drinking water. Group I was treated with ig propolis at $150 \mathrm{mg} / \mathrm{kg}$, for 44 weeks, beginning 30 days before the start of BBN. Groups IIA, III were treated with propolis $(150 \mathrm{mg} / \mathrm{kg})$, for 40 weeks, sc and ig, respectively, started simultaneously with BBN. On the 32nd week, the animals of groups L, M and N, were treated ig with L-lysine $(300 \mathrm{mg} / \mathrm{kg}$ ), celecoxib (30 mg/kg) and propolis (300 mg/kg), respectively, up to the 40th week. The groups that received only BBN (IIB and K) were treated with water, sc and oral, respectively, for 40 weeks. Groups XI, XII and XIII received respectively propolis (150 mg/ $\mathrm{kg}$ ), $L$-lysine $(150 \mathrm{mg} / \mathrm{kg}$ ) and water ig for 40 weeks (Figure 1). At the end of 40 weeks, the survivors were anesthetized and subjected to bone marrow aspiration from the femur and blood sampling from the aorta for CA and MNT, respectively, for determination of genotoxicity.

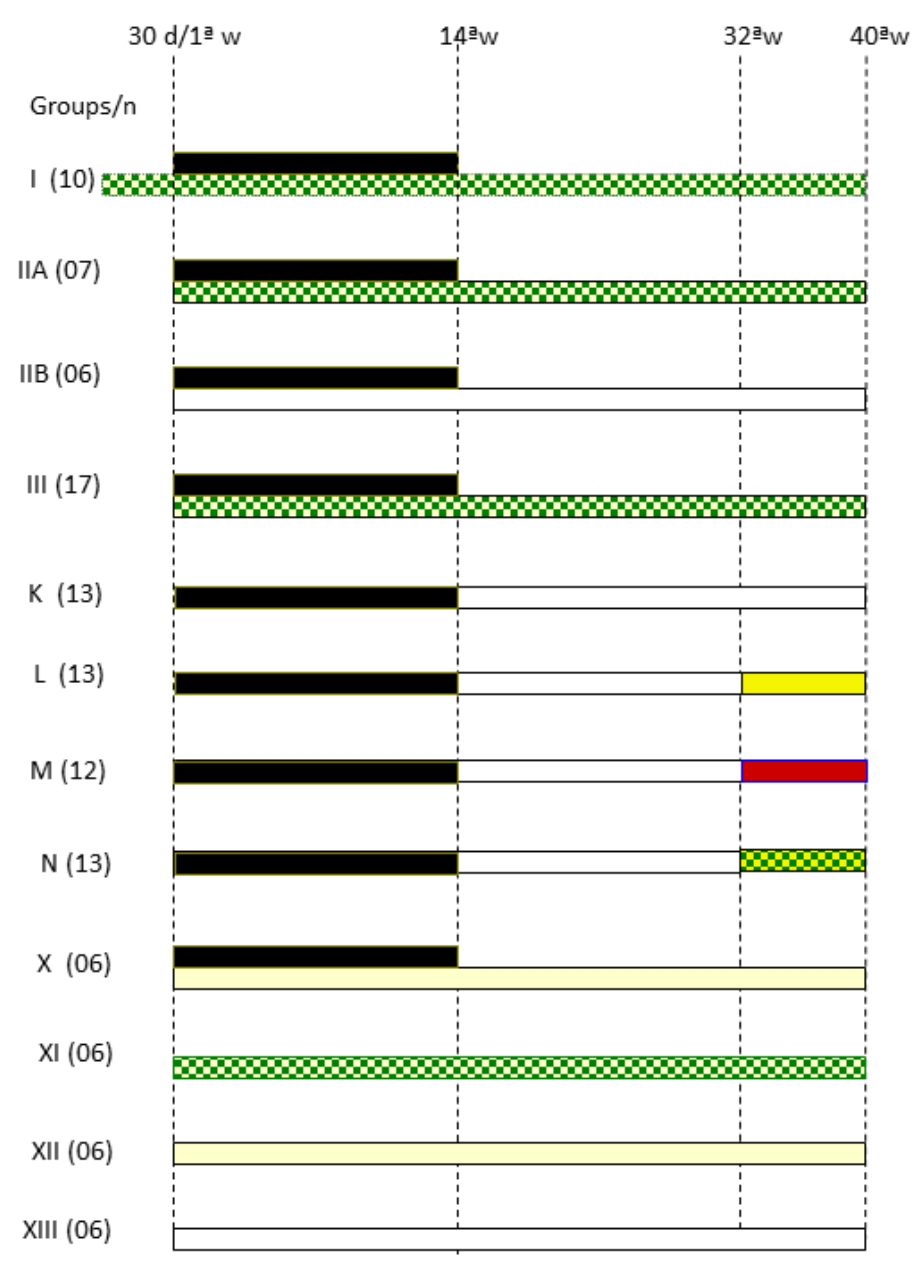

FIGURE 1 - Experimental design.

Propolis $(150 \mathrm{mg} / \mathrm{kg}$ ) 度, $L$-lysine $(150 \mathrm{mg} / \mathrm{kg}) \square$, BBN (0.05\% drinking water)

celecoxib (30mg/kg) $\square, \mathrm{H}_{2} \mathrm{O}$

Propolis double dose $(300 \mathrm{mg} / \mathrm{kg})$ \%, -lysine double dose $(300 \mathrm{mg} / \mathrm{kg})$ $\mathrm{n}$ - number of animals, $\mathrm{d}$ - day, w-week.

Intragastric administration, single dose daily I, III, X, L, M, XI, XII, XIII.

Subcutaneous administration, single dose daily IIA and IIB. 


\section{Bone-marrow micronucleus test}

Before the animals were euthanized, both femoral were dissected (Figure 2) and the marrow cells were flushed out with $1 \mathrm{~mL}$ fetal bovine serum and pipetted several times. The cell suspension was centrifuged $(200 \times \mathrm{g}$ for $5 \mathrm{~min})$ and the supernatant discarded. The cell pellet was then resuspended and placed on a clean glass slide. Two slides were analyzed per animal. The slides were dried overnight, refreshed with concentrated Leishman stain for $3 \mathrm{~min}$ and counterstained with diluted Leishman stain (1:6) for $15 \mathrm{~min}$. The slides were scored under a light microscope at $40 \mathrm{X}$ magnification. The percentage of micronucleated cells was determined relative to a blinded differential count of 4000 polychromatic erythrocytes (PCE) per animal ${ }^{10,11}$.

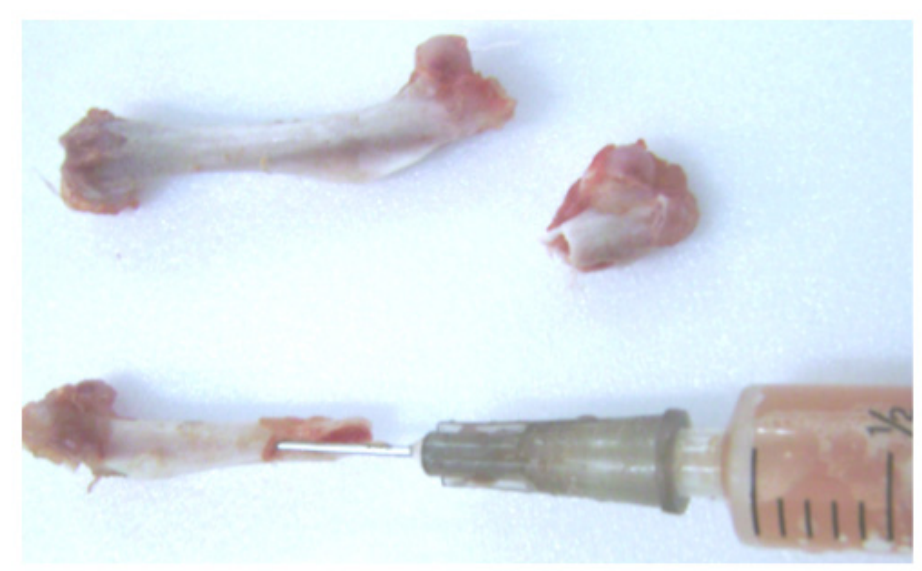

FIGURE 2 - Aspiration of bone marrow from femur.

\section{Alkaline comet assay}

The experiments were carried out according to Hartmann et al..$^{12}$. The survivors at 40 weeks were used for each experimental group, where slides were prepared from each sample and 100 nuclei/animal were evaluated per slide. Briefly, whole blood (10 $\mu \mathrm{L}$ ) (Figure 3 ) were dissolved in $0.75 \%$ low melting point agarose and immediately spread onto a glass microscope slide precoated with a layer of $1 \%$ normal melting point agarose. The agarose was allowed to set at $4^{\circ} \mathrm{C}$ for $5 \mathrm{~min}$. The slides were incubated in icecold lysis solution $(2.5 \mathrm{M} \mathrm{NaCl}, 10 \mathrm{mM}$ Tris, $100 \mathrm{mM}$ EDTA, $1 \%$ Triton $\mathrm{X}-100$ and $10 \% \mathrm{DMSO}, \mathrm{pH} 10.0$ ) at $4^{\circ} \mathrm{C}$ for at least $1 \mathrm{~h}$ to remove cellular proteins, leaving the DNA as nucleoids. After the lysis procedure, the slides were placed on a horizontal electrophoresis unit. The unit was filled with fresh buffer (300 $\mathrm{mM} \mathrm{NaOH}$ and $1 \mathrm{mM}$ EDTA, $\mathrm{pH}>13.0$ ) to cover the slides for $20 \mathrm{~min}$ at $4{ }^{\circ} \mathrm{C}$ to allow DNA unwinding and exposure of alkalilabile sites. Electrophoresis was conducted for 20 min at $25 \mathrm{~V} \mathrm{(300}$
$\mathrm{mA}$ ). All the above steps were conducted under yellow light or in the dark to prevent additional DNA damage. The slides were then neutralized (0.4 M Tris, $\mathrm{pH} 7.5)$, dried with $100 \%$ ethanol, stained with ethidium bromide $(20 \mu \mathrm{g} / \mathrm{mL})$, and analyzed using a fluorescence microscope. Cells were scored visually and assigned to one of five classes, according to tail size (from undamaged: 0 , to maximally damaged: 4) (Table 1 and Figure 4), and the DNA damage index (DI) was calculated for each sample of cells. DI thus ranged from 0 (completely undamaged: 100 cells $\times 0$ ) to 400 (with maximum damage: 100 cells $\times 4)^{13}$.

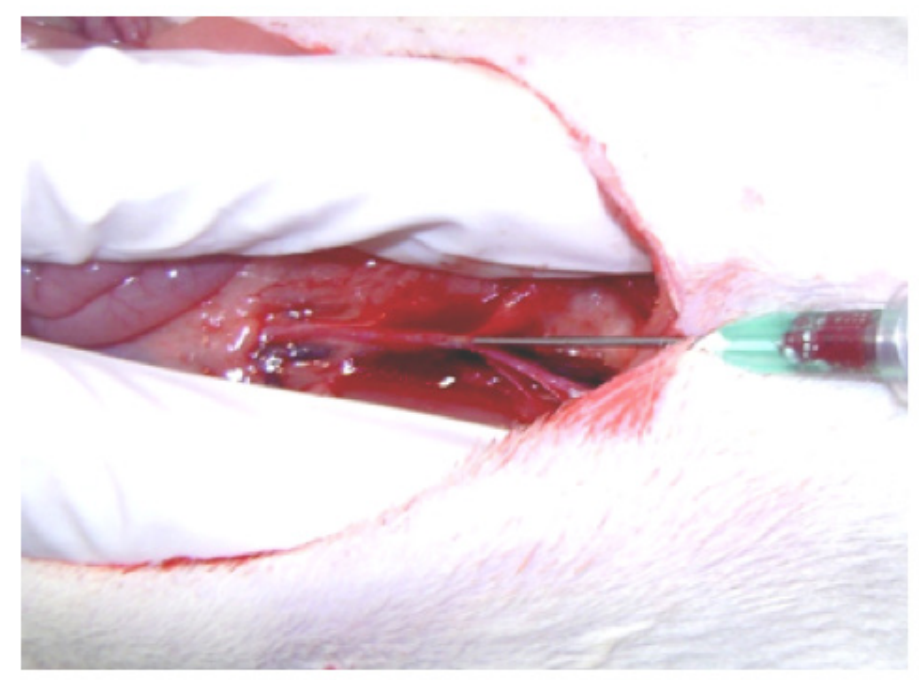

FIGURE 3 - Drawing blood from abdominal aorta.

TABLE 1 - Damage index is given by the formula DI $=(0 \mathrm{x}$ $n 0)+(1 \times n 1)+(2 \times n 2)+(3 \times n 3)+(4 \times n 4)$, where $n$ is the number of comets of the respective classes.

\begin{tabular}{ccc}
\hline Class & DNA damage & \% damage \\
\hline 0 & None & $<5 \%$ \\
1 & Low level & $5-20 \%$ \\
2 & Medium level & $20-40 \%$ \\
3 & High level & $40-95 \%$ \\
4 & Maximal & $>95 \%$ \\
\hline
\end{tabular}
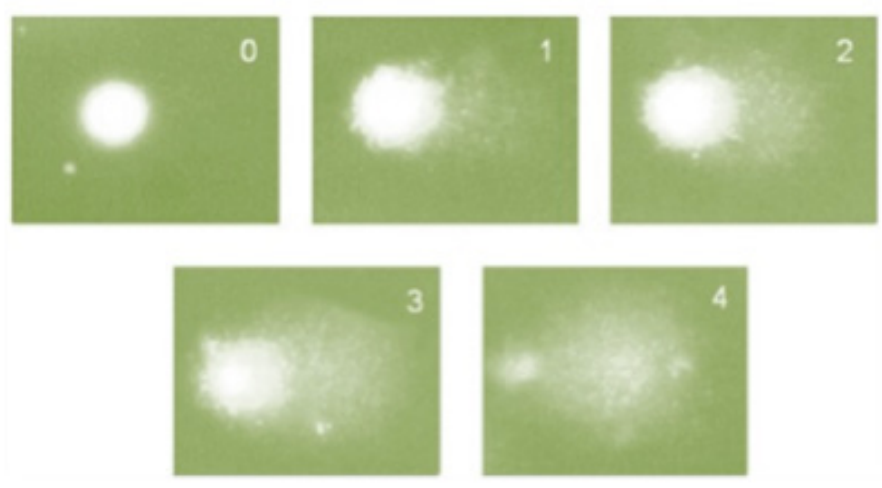

FIGURE 4 - Classes for determination of comet assay damage index ( 0 , $1,2,3$ and 4). 


\section{RESULTS}

Mean and standard deviation of DI of rats effectively evaluated are given in Table 2.

TABLE 2 - Groups, number of rats effectively evaluated (N) and mean and standard deviation of DNA damage index.

\begin{tabular}{cccc}
\hline \multirow{2}{*}{ Groups } & \multirow{2}{*}{$\mathbf{N}$} & \multicolumn{2}{c}{ DNA DAMAGE INDEX } \\
\cline { 3 - 4 } & & MEAN & $\mathbf{\mathbf { S D }}$ \\
\hline GI & 10 & $\mathbf{1 5 . 7 0}$ & 6.26 \\
GIIA & 5 & 7.40 & 2.61 \\
GIIB & 6 & 37.17 & 7.62 \\
GIII & 6 & 13.08 & 1.28 \\
GK & 9 & 42.83 & 8.19 \\
GL & 8 & 10.50 & 4.42 \\
GM & 8 & 10.94 & 4.77 \\
GN & 8 & 11.56 & 3.67 \\
GX & 4 & 6.88 & 1.93 \\
GXI & 5 & 10.70 & 3.88 \\
GXII & 5 & 7.30 & 3.87 \\
GXIII & 6 & 6.25 & 2.21 \\
\hline
\end{tabular}

Groups IIB and $\mathrm{K}$, which received only $\mathrm{BBN}$ and water, showed higher DI in leukocytes (CA) with means of $37.17 \pm 7.62$ and $42.83 \pm 8.19$, respectively, in relation to all other groups, which received $\mathrm{BBN}$ and lysine and/or propolis and celecoxib (Groups I, II, III, X, L, M N) ( $<<0.001$, Table 2 and Figure 5).

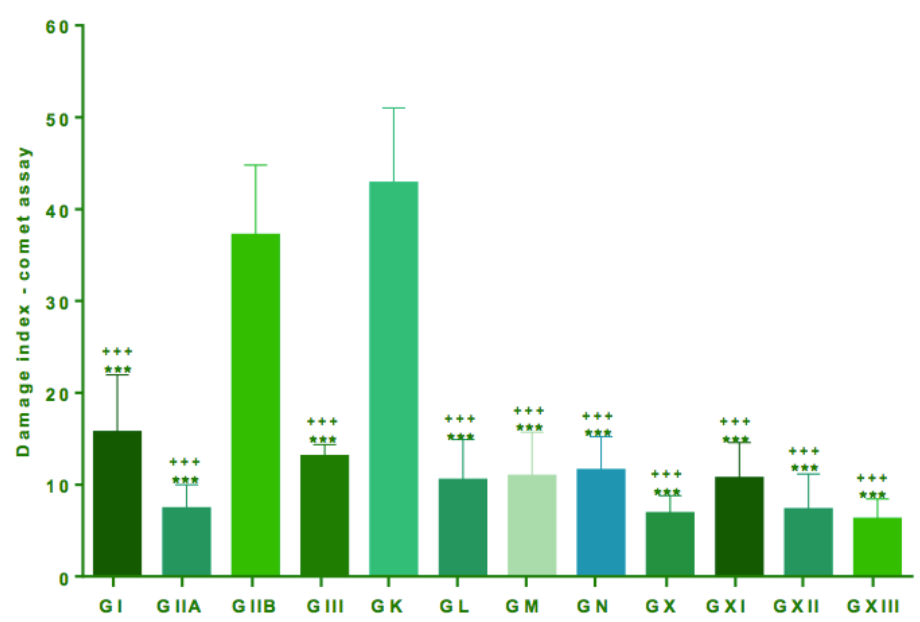

FIGURE 5 - Comet assay performed in blood lymphocytes for evaluation of DNA damage. Quantification of damage to lymphocytes expressed as mean and standard deviation. Comparisons between the groups were made by analysis of variance (ANOVA) followed by Tukey's multiple comparisons test.

${ }^{* * *}$ All groups with lower DI when compared with groups IIB $(\mathrm{p}<0.001)$

${ }^{++}$All groups with lower DI when compared with groups $\mathrm{K}(\mathrm{p}<0.001)$
Table 3 presents the details of the animals evaluated with respect to mean and standard deviation of micronuclei in PCE. In the evaluation of micronuclei in erythroblasts (MNT), groups IIB and $\mathrm{K}$ (percentage of micronuclei in PCEs of $15.3 \pm 4.01$ and 12.4 \pm 2.12 , respectively) showed similar result when comparing the controls with the other groups that received BBN and lysine and/ or propolis and celecoxib (Groups I, IIA, III X, L, M and N) (Table 3 and Figure 6).

TABLE 3 - Groups, number of rats effectively evaluated (N), mean and standard deviation of percentage of micronuclei (PCE-MN $\mathrm{MEAN} \pm \mathrm{SD})$.

\begin{tabular}{cccc}
\hline Groups & $\mathrm{N}$ & \multicolumn{2}{c}{ EPC-MN } \\
\cline { 3 - 4 } & & MEAN & \pm SD \\
\hline GI & 10 & 5.30 & 2.16 \\
GIIA & 5 & 5.10 & 2.19 \\
GIIB & 6 & 15.3 & 4.01 \\
GIII & 6 & 5.42 & 1.39 \\
GK & 9 & 12.4 & 2.12 \\
GL & 8 & 7.88 & 1,48 \\
GM & 8 & 6.31 & 2.12 \\
GN & 8 & 8.25 & 2.93 \\
GX & 4 & 5.88 & 1.80 \\
GXI & 5 & 3.60 & 1.19 \\
GXII & 5 & 4.60 & 1.71 \\
GXIII & 6 & 2.58 & 1.07 \\
\hline
\end{tabular}

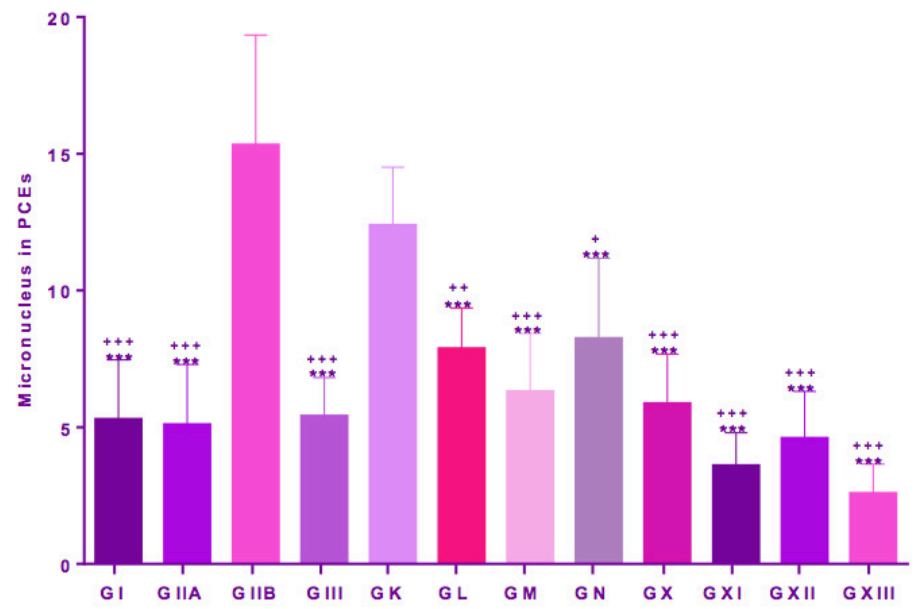

FIGURE 6 - Micronucleus test performed in smears of bone marrow aspirate from femur. Quantification of micronuclei and comparison between the groups. Data expressed as mean and standard deviation of percentages. Comparisons between the groups were made by analysis of variance (ANOVA) followed by Tukey's multiple comparisons test.

***All groups with lower percentage of micronuclei in PCE when compared to group IIB $(\mathrm{p}<0.001)$

${ }^{++}$Groups with lower percentage of micronuclei in PCE when compared to group $\mathrm{K}(\mathrm{p}<0.001)$

${ }^{++}$Group with lower percentage of micronuclei in PCE when compared to group $\mathrm{K}(\mathrm{p}<0.01)$

${ }^{+}$Group with lower percentage of micronuclei in PCE when compared to group $\mathrm{K}$ $(\mathrm{p}<0.05)$ 
The groups that did not receive BBN, XI, XII and XIII, did not exhibit genotoxity according to the two methods used (XI was given propolis extracted in $L$-lysine, and XII only $L$-lysine and XIII only water).

\section{Discussion}

This work is a continuation of earlier studies published by Dornelas et al. ${ }^{7,9}$ whose objective was to evaluate the effect of green propolis and $L$-lysine on carcinogenesis and angiogenesis in rats subjected to chemical carcinogenesis of the bladder. In the earlier studies, we found that propolis administered to rats inhibited angiogenesis and bladder carcinogenesis in this model at the doses studied and that $L$-lysine promoted bladder carcinogenesis. The animals given only $L$-lysine for 40 weeks did not develop cancer, but on the other hand, in the animals that received carcinogen and L-lysine, the lesions were more invasive than in the group given only carcinogen. This finding indicated that at these doses $L$-lysine does not induce bladder carcinogenesis but only promotes it. It was uncertain as to if propolis and $L$-lysine exerted or not a protective effect in bone marrow of animals subjected to bladder carcinogenesis. Would propolis and $L$-lysine at that doses and times be genotoxic to bone marrow and blood peripheral leukocytes? Animals from those experiments that survived up to the 40th week, were then subjected to the two tests for evaluation of genotoxicity.

DI is an arbitrary measure (without units utilized for assessing the extent of DNA lesions (Table 1 and Figure 4).

The MNT and CA results showed that both $L$-lysine and propolis extracted in lysine for the times and doses tested were not genotoxic in rats. Furthermore, they significantly protected against the genotoxicity of BBN, when compared with the controls. Tavares et al. ${ }^{14}$ carried out genotoxicity tests on propolis in ovarian cells and found that higher concentrations were genotoxic while lower concentrations protected against genotoxicity. Other authors obtained similar results when testing compounds isolated from green propolis or Bacharris dracuncfolia (plant that bees visit for production of green propolis $\left.{ }^{15}\right)$. $L$-Lysine did not show genotoxicity in bone marrow cells, like in the transitional epithelial cells of the bladder in the same animal, despite promoting bladder carcinogenesis after its initiation with BBN.

Micronuclei are analyzed in polychromatic erythrocytes, which are erythrocytes in an intermediate stage of development and contain RNA, where they therefore can be distinguished by selective staining from mature normochromatic erythrocytes lacking RNA. The determination of the proportion of polychromatic erythrocytes and normochromatic erythrocytes is important in the detection of excessive toxicity in the bone marrow. Toxicity is expressed as the percentage of polychromatic erythrocytes. The life span of these erythrocytes is relatively short, such that any micronucleus present should have been produced as a result of recently induced chromosomal damage ${ }^{16,17}$. However, we see that in groups IIB and $\mathrm{K}$ at 40 weeks, many cells exhibited increased micronuclei in bone marrow cells even after stopping the administration of carcinogens after 14 weeks. It should be recalled that $\mathrm{BBN}$ is a complete carcinogen and can cause definitive genomic alterations, which could have occurred.

An explanation for the genotoxic damage observed by the occurrence of micronuclei in the erythroblasts and the finding of satellites in these cells after a long lapse of time, can lie in the permanent genotoxicity in the precursors of the cells analyzed. In clinical practice, most cancer patients undergo chemotherapy or radiotherapy, which is potentially genotoxic and can lead to the development of a second malignant neoplasm ${ }^{18,19}$.

The tests also showed that celecoxib, propolis and $L$-lysine (at two times higher dose) initiated in the 32nd week were also able to significantly reduce cellular genotoxic damage when compared with the controls that were subjected to BBN. It should be recalled that BBN was administered for up to 14 weeks, and both CA and MNT demonstrated significant reduction in damage in relation to the controls that received only carcinogen. This could be a case of reversal of the genotoxic effect of BBN (could the genotoxic alteration be an epigenetic process in this case?) or, alternatively, the occurrence of apoptosis of precursor cells? What would be the mechanism of action of propolis, $L$-lysine and celecoxib? Could they have a similar action in bone marrow? Experimental and pre-clinical studies have shown a promising future for celecoxib combined with other agents in the treatment of cancer ${ }^{20-22}$. Celecoxib is a highly selective COX-2 inhibitor and can induce apoptosis in MGC803 gastric cancer cells through a mechanism that involves cell cycle arrest, mitochondrial release of cytochrome $\mathrm{C}$ and activation of caspases ${ }^{23}$. The promising results and the cardiotoxic effects of celecoxib have prompted the scientific community to develop a synthetic derivative that is effective in the treatment of cancer without producing collateral effects.

\section{Conclusion}

Both propolis and $L$-lysine and celecoxib are effective in the protection and/or reversal of genotoxicity by BBN, in the cells specifically evaluated (bone marrow erythrocytes and blood leukocytes) at the times and doses tested. Propolis as well as $L$-lysine at the doses and times used, are not genotoxic in the cells evaluated, according to the two tests applied. 


\section{References}

1. Fearon ER, Vogelstein B. A genetic model for colorectal tumorigenesis. Cell. 1990 Jun 1;61:759-67. PubMed PMID: 2188735.

2. Orsolić N, Kosalek I, Basić I. Synergistic antitumor effect of polyphenolic components of water soluble derivative of propolis against Ehrlich ascites tumour. Biol Pharm Bull. 2005 Apr;28(4):694700. PubMed PMID: 15802812.

3. Orsolić N, Basić I. Water-soluble derivative of propolis and its polyphenolic compounds enhance tumoricidal activity of macrophages. J Ethnopharmacol. 2005 Oct 31;102(1):37-45. PubMed PMID: 16054317.

4. Oršolić N, Benković V, Lisičić D, Dikić D, Erhardt J, Knežević AH. Protective effects of propolis and related polyphenolic/flavonoid compounds against toxicity induced by irinotecan. Med Oncol. 2010 Dec;27(4):1346-58. doi: 10.1007/s12032-009-9387-5.

5. Dimov V, Ivanovska N, Manolova N, Bancova V, Nikolov N, Popov, S. Immunomodulatory action of propolis. Influence on anti-infectious protection and macrophage function. Apidologie. 1991;22:155-62. doi: 10.1051/apido:19910208.

6. Song YS, Park EH, Jung KJ, Jin C. Inhibition of angiogenesis by propolis. Arch Pharmacol Res. 2002 Aug;25:500-4. PubMed PMID: 12214863.

7. Dornelas, CA, Fechine-Jamacaru FV, Albuquerque IL, Magalhães HI, Souza AJ, Alves LA, Almeida PR, Lemos TL, Castro JD, Moraes ME, Moraes MO. Chemoprevention with green propolis green propolis extracted in L-lysine versus carcinogenesis promotion with L-lysine in N-Butyl-N-[4-hydroxybutyl] nitrosamine (BBN) induced rat bladder cancer. Acta Cir Bras. 2012 Feb;27(2):185-92. PubMed PMID: 22378376.

8. Nicolov N, Marekov N, Bancova V, Popov S, Ignatov R, Valdimirova I. Method for the preparation of water-soluble derivative of propolis. 1987, Patent no. 79903, Sofia, Bulgaria.

9. Dornelas CA, Fechine-Jamacaru FV, Albuquerque IL, Magalhães HI, Dias TA, Faria MH, Alves MK, Rabenhorst SH, de Almeida PR, Lemos TL, Castro JD, Moraes ME, Moraes MO. Angiogenesis inhibition by green propolis and the angiogenic effect of L-lysine on bladder cancer in rats. Acta Cir Bras. 2012 Aug;27(8):529-36. PubMed PMID: 22850703.

10. Hayashi M, Tice, R R, MacGregor JT, Anderson D, Blakey D, Kirsh-Volders M, Oleson FB, Pachierotiti F, Shimada H, Sutuo S, Vannier B. In vivo rodent erythrocyte micronucleus assay. Mutat Res. 1994 Jun;312(3):293-304. PubMed PMID: 7514741.

11. Ramos ME, Cavalcanti BC, Lotufo LV, de Moraes MO, Cerqueira, Ede M, Pessoa C. Evaluation of mutagenic effects of formocresol: detection of DNA-protein cross-links and micronucleus in mouse bone marrow. Oral Surg Oral Med Oral Pathol Oral Radiol Endod. 2008 Mar;105(3):398-404. doi: 10.1016/j.tripleo.2007.08.009.

12. Hartmann A, Agurell E, Beevers C, Brendler-Schwaab S, Burlinson B, Clay P, Collins A, Smith A, Speit G, Thybaud V, Tice RR. Recommendations for conducting the in vivo alkaline Comet assay. 4th International Comet Assay Workshop. Mutagenesis. 2003;18(1):45-51. PubMed PMID: 12473734.

13. Collins A, Dusinská M, Franklin M, Somorovská M, Petrovská H, Duthie S, Fillion L, Panayiotidis M, Raslová K, Vaughan N. Comet assay in human biomonitoring studies: reliability, validation, and applications. Environ Mol Mutagen. 1997;30(2):139-46. PubMed PMID: 9329638.

14. Tavares DC, Mazzaron Barcelos GR, Silva LF, Chacon Tonin CC, Bastos JK. Propolis-induced genotoxicity and antigenotoxicity in Chinese hamster ovary cells. Toxicol In Vitro. 2006 Oct;20 (7): 1548. PubMed PMID: 16682170.
15. de Oliveira PF, Lima IM, Monteiro Neto Mde A, Bastos JK, da Silva Filho AA, Tavares DC. Evaluation of genotoxicity and antigenotoxicity of artepillin C in V79 cells by the comet and micronucleus assays. Nutr Cancer. 2013;65(7):1098-103. doi: 10.1080/01635581.2013.815233.

16. Rabello-Gay MN, Rodrigues MALR, Monteleone-Neto R. Mutagênese, teratogênese e carcinogênese: métodos e critérios de avaliação. Sociedade Brasileira de Genética. Ribeirão Preto; 1991.

17. Ribeiro LR, Salvadori DMF, Marques EK. Mutagênese ambiental. Canoas: Ed. ULBRA; 2003.

18. Aidan, JC, Priddee NR, McAleer JJ. Chemotherapy causes cancer! A case report of therapy related acute myeloid leukaemia in early stage breast cancer. Ulster Med J. 2013 May;82 (2):97-9. PubMed PMID: 24082288.

19. Travis LB, Ng AK, Allan JM, Pui CH, Kennedy AR, Xu XG, Purdy JA. Applegate K, Yahalom J, Constine LS, Gilbert ES, Boice JD Jr. Second malignant neoplasms and cardiovascular disease following radiotherapy. Health Phys. 2014 Feb;106(2):229-46. doi: 10.1097/ HP.0000000000000013.

20. Fischer SM, Hawk ET, Lubet RA. Coxibs and other nonsteroidal antiinflammatory drugs in animal models of cancer chemoprevention. Cancer Prev Res (Phila). 2011 Nov;4(11):1728-35. doi: 10.1158/1940-6207.CAPR-11-0166.

21. Zhang H, Tian M, Xiu C, Wang Y, Tang G. Enhancement of antitumor activity by combination of tumor lysate-pulsed dendritic cells and celecoxib in a rat glioma model. Oncol Res. 2013;20(10):447-55. PubMed PMID: 24308155.

22. Saba N, Hurwitz SJ, Kono S, Yang CS, Zhao Y, Chen Z, Sica G, Muller S, Moreno-Williams R, Lewis M, Grist W, Chen AY, Moore CE, Owonikoko TK, Ramalingam S, Beitler JJ, Nannapaneni S, Shin HJ, Grandis JR, Khuri FR, Chen ZG, Shin DM. Chemoprevention of head and neck cancer with celecoxib and erlotinib: results of a phase ib and pharmacokinetic study. Cancer Prev Res (Phila). 2014 Mar;7(3):283-91. doi: 10.1158/1940-6207.CAPR-13-0215.

23. Wang YJ, Niu XP, Yang L, Han Z, Ma YJ. Effects of celecoxib on cycle kinetics of gastric cancer cells and protein expression of cytochrome C and caspase-9. Asian Pac J Cancer Prev. 2013;14(4):2343-7. PubMed PMID: 23725138.

\section{Correspondence:}

Profa. Conceição Aparecida Dornelas

Faculdade de Medicina

Departamento de Patologia e Medicina Legal

Rua Monsenhor Furtado, s/n

60441-750 Fortaleza - CE Brasil

Tel.: (55 85)3366-8300/3366-8301

Fax: (55 85)3366-8201

eusoucondor@yahoo.com.br

Received: Feb 20, 2014

Review: April 22, 2014

Accepted: May 19, 2014

Conflict of interest: none

Financial source: none

${ }^{1}$ Research performed at Laboratory of Experimental Surgery, Department of Surgery, Faculty of Medicine, Federal University of Ceara (UFC), Brazil. Part of PhD degree thesis, Postgraduate Program in Surgery. Tutor: Prof Manoel Odorico de Moraes. 